International Journal on Information Theory (IJIT) Vol.6, No.1/2, April 2017

\title{
The Effect Of Financial Crises On The ENTROPY EVOLUTION OF FOREIGN EXCHANGE RATES
}

\author{
Cleo S. Villanueva ${ }^{1}$ and Jasmin DC. Niguidula ${ }^{2}$ \\ ${ }^{1}$ Capiz State University - Pontevedra Campus, Capiz, Philippines \\ ${ }^{2}$ Technological Institute of the Philippines, Manila, Philippines
}

\begin{abstract}
This study investigates the possible effect of financial crises on foreign exchange markets, where entropy (using the time-dependent block entropy method) for different exchange rates is measured. Results suggest that financial crises are associated with significant increase of exchange rate entropy especially in US and Hongkong currencies, reflecting instability in FX market dynamics. Moreover, for most of the currencies studied, increase of exchange rate entropy was observed after a period of financial crisis. In addition, empirical results show that periods of economic uncertainty are led by periods of low entropy values, which might serve as indicator for anticipating the inception of financial crises.
\end{abstract}

\section{KEYWORDS}

Shannon entropy, time-dependent entropy, foreign exchange rates, financial crisis

\section{INTRODUCTION}

Exchange rate is defined as one country's currency converted into another country's currency (Khan \& Jain, n.d.). Exchange rate movement is an essential topic of macroeconomic analysis and market investigation. Exchange rates are important in every country because it affects and influence number of factors which include the economy. Foreign exchange (FX) rates portray an important role in the FX market which is the biggest and most free-flowing financial market across countries. Currency movements have long-term influence on economic activity such as economic growth, exports and imports, and inflation of prices (Kandil, et al., 2007).

Exchange rates display extreme fluctuations in time of financial crisis despite of trivial movements of most of the times (Melvin, et. al, 2009; Baba, et al. (2009); Kohler (2010), which could be temporarily interpreted by flows from and to refuge currencies as investors search for more reliable assets. It could be vital for forestalling consequences of global financial crises in the future the knowledge of underlying forces of such fluctuations in FX markets.

As cited by Darko in 2015 a stock price - Brownian motion model was proposed by Bachelier signifying that price variations could be illustrated by random processes. Consequently, a developing market theory from Bachelier's work noted that prices would exhibit random walk behavior if a market is efficient. All necessary information to the FX rate is endogenous to the current value of an amount to be received in the future (or present value) of a currency as claimed

DOI : $10.5121 /$ ijit.2017.6201 
by the FX markets' efficient market hypothesis (EMH) (Fama,1970;1984). However, various studies (Lo, et al, 1988; 2011; Chang (2004); Chuluun, et al. (2011); display that FX markets could be not efficient and depart from a random walk manner. Numerous statistical methods were suggested to quantify efficiency of the market (Cajueiro, et al. (2004); Sensoy (2013); Zunino, et al. (2008)), lately more concentration were given on methods based in entropy such as multi-scale entropy, approximate entropy, Shannon entropy, permutation entropy, Tsallis entropy, and Renyi entropy.

This study utilized entropy introduced by Shannon which revealed as an effective numerical method in different phenomenal studies such as in finance, engineering, hydrology, etc. Shannon entropy computes the chaos quantity existing in a sequence. Entropy could be utilized to any progressions where likelihoods appears as proposed by Shannon \&Wever in 2002, which followed by many works calculating entropy in time series involving finance.

Analysis involving entropy has also given much consideration in finance due to its ability to extract information that were concealed by the disordered structure of the series. Since in nonstationary series, the use of classical entropy methods is not that efficient, entropy in time series means were presented, which create a chronological evolution of entropy.

Specifically, this study investigated the financial crises' influence on FX markets, where using the method of block entropy that is dependent on time, the development of entropy is computed for various exchange rates. It uses a numerous sign discretization structure which catches all the possible fluctuations on a day-to-day chronological level.

The entropy development is assessed for various FX rates in a certain time period. During different financial crises, entropy changes were assessed and compared between different FX markets.

\section{Methodology}

\subsection{Block Entropy in Time Series}

Entropy is an amount of chaos in the series. In 2002, Shannon \& Weaver formulated entropy that could be viewed as the average quantity of data encrypted in a sequence obtained from a probability distribution in information theory. The classical Shannon entropy is given by

$$
\mathrm{S}(\mathrm{X})=-\sum_{i=1}^{m} p_{i} \log p_{i}
$$

Where $\mathrm{X}$ is a time series random variable with possible values $\mathrm{x}_{1}, \ldots, \mathrm{x}_{\mathrm{m}}$ $\mathrm{p}_{\mathrm{i}}$ is the probability of $\mathrm{X}$ assuming the value $\mathrm{x}_{\mathrm{i}}$.

Entropy is maximum $\mathrm{S}(\mathrm{X})=\log \mathrm{m}$ when all values $\mathrm{x}_{\mathrm{i}}, \mathrm{i}=1 \ldots \mathrm{M}$, are equally likely, or more precisely $\mathrm{p}_{1}=\mathrm{p}_{2}=\cdots=\mathrm{p}_{\mathrm{m}}=1 / \mathrm{m}$. On the other hand, entropy is minimum $\mathrm{S}(\mathrm{X})=0$ when a single value $\mathrm{x}_{\mathrm{i}}$ collects all the likelihood and is sure to occur. Entropy approximating $\log \mathrm{m}$ evokes that the system is nearly random and could be explained with elevated market efficiency (Sakalauskas, 2011). Though Entropy measures the average randomness of a system, it cannot always useful for analyzing nonstationarities (Darbellay, 2000). Hence, numerous measures on information could be utilized to time series that are nonstationary. The entropy measure on 
financial time series is patterned on the technique of sliding window and produces an entropy's chronological development.

In 2002, Shannon further proposed that Entropy could be used to any progressions where likelihoods exist. The entropy assesses the chaos' quantity in a series. The notion of entropy has been widely used in finance since it could obtain information that are hidden in the disordered arrangement of the progression. Since classical entropy methods is inefficient for time series that are nonstationary, entropy measures for time series were adopted which produce entropy's chronological development.

The influence of global financial crises on FX markets by means of numerous discretization arrangement that catches all the probable movements on a day-to-day chronological scale is assessed in this study. Behavior of market strength among 13 different FX rates relative to Philippine peso in a period that ranges from 2000 to 2017. The development of entropy is assessed for logarithmic returns of the FX rates understudy and variations are investigated during 2007 to 2009 global financial crisis, and evaluated among various forex markets.

\section{EMPIRICAL ANALYSIS}

The daily fluctuations of 13 various FX rates that ranges from 2000 to 2017 were analyzed. Currency names by continent, currency code, forex market trend strength, and period covered are shown in Table 1. The forex market strength is measured by Relative Strength Index (RSI) provided by www.investing.comfor the period January 2000 to February 2017. RSI, as an oscillator, would deliver a value that ranges from one to 100, inclusive, and would express the price strength had been for the number of periods observed. For RSI below 30, it means weak price action. For RSI above 70, then there is a strong price action. For each foreign currency, the logarithmic returns $R_{i}(t)=\ln X_{t}(t+\Delta t)-\ln X_{t}(t)$, where $X_{t}(t)$ is considered to be the closing exchange rate in a day at a given time $t$. Then, the time series on logarithmic returns is converted to a notation symbols of quantities for the classical Shannon entropy. At different time intervals (every three years) using an order of $L$ symbols, the entropy is calculated.

\begin{tabular}{|l|c|c|c|}
\hline \multicolumn{1}{|c|}{ Currency Name } & Symbol & $\begin{array}{c}\text { Period covered } \\
(\mathrm{dd} / \mathrm{mm} / \mathrm{yy})\end{array}$ & $\begin{array}{c}\text { FX Market Strength } \\
\text { relative to PhP }\end{array}$ \\
\hline ASIA & & $01 / 03 / 00-02 / 10 / 17$ & Strong \\
\hline 1. Japanese Yen & JPY & $01 / 03 / 00-02 / 10 / 17$ & Strong \\
\hline 2. Singapore Dollar & SGD & $01 / 03 / 00-02 / 10 / 17$ & Strong \\
\hline 3. Hongkong Dollar & HKD & $01 / 03 / 00-02 / 10 / 17$ & Strong \\
\hline $\begin{array}{l}\text { 4. Chinese Yuan } \\
\text { (Renminbi) }\end{array}$ & CNY & & Weak \\
\hline EUROPE & GBP & $01 / 03 / 00-02 / 10 / 17$ & Weak \\
\hline 5. British Pound & EUR & $01 / 03 / 00-02 / 10 / 17$ & Strong \\
\hline 6. Euro & CHF & $01 / 03 / 00-02 / 10 / 17$ & Strong \\
\hline 7. Swiss Franc & & & Strong \\
\hline $\begin{array}{l}\text { NORTH } \\
\text { AMERICA }\end{array}$ & USD & $01 / 03 / 00-02 / 10 / 17$ & \\
\hline 8. US dollar & CAD & $01 / 03 / 00-02 / 10 / 17$ & \\
\hline 9. Canadian Dollar & & & \\
\hline MIDDLE EAST & & & \\
\hline
\end{tabular}


International Journal on Information Theory (IJIT) Vol.6, No.1/2, April 2017

\begin{tabular}{|l|l|l|l|}
\hline $\begin{array}{l}\text { 10.Saudi Arabia } \\
\text { Riyal }\end{array}$ & SAR & $01 / 03 / 00-02 / 10 / 17$ & Strong \\
\hline $\begin{array}{l}\text { 11.United Arab } \\
\text { Emirates Dirham }\end{array}$ & AED & $11 / 26 / 04-02 / 10 / 17$ & Strong \\
\hline PACIFIC & AUD & $01 / 03 / 00-02 / 10 / 17$ & Strong \\
\hline 12.Australian Dollar & NZD & $01 / 03 / 00-02 / 10 / 17$ & Strong \\
\hline $\begin{array}{l}\text { 13. New Zealand } \\
\text { Dollar }\end{array}$ & & & \\
\hline
\end{tabular}

Table 1. Characteristics of FX rates.

The entropy in time series was used to logarithmic returns on daily basis of FX rates and periods as enumerated in Table 1. Simulations were done using window of $w=3$ years or approximately 782 days, on the average to capture fluctuations of FX rates due to global financial crisis (2007 to 2009) and setting the sliding step to $\Delta=$ one day. Then, individual window is split into $M=$ ten (10) disjoint intervals for symbolization, where every symbol corresponds to different magnitudes of '+' (positive) and '-' (negative) returns. The numerous sign method permits catching data of different variations in the system. Then, for each window, probability $\left(\mathrm{p}_{\mathrm{i}}\right)$ is computed for each distinct sequences formed that represents variations in the system and lastly, using these $\mathrm{p}_{\mathrm{i}}$ 's, the Shannon entropy is computed using $\mathrm{L}=6$ daily logarithmic returns sequences as blocks.

Table 2 displays the entropy coefficient and economic data of the currencies under study. The public data on GDP growth for each currency under consideration were collected in the world development indicators provided by World Bank's website. Financial crisis and currencies yield concerns in the economic activity of the countries under study. The gross domestic product (GDP) of Japan dropped 5.53 percent during financial crisis in 2009 and displayed a depressed economic rate of growth (about 0.74 percent)in the observed period. The Eurozone or Euro area which consists primarily of the countries in the European Union like Germany dropped 5.62 percent during also the financial crisis in 2009, however, its economic rate of growth in the period covered is about 4 percent.

\begin{tabular}{|c|c|c|c|c|c|c|}
\hline FX MARKET & $\begin{array}{c}\text { Entropy } \\
\text { Coefficie } \\
\text { nts }\end{array}$ & $\begin{array}{c}\text { Standard } \\
\text { Deviatio } \\
n\end{array}$ & $\begin{array}{l}\text { Min } \\
\text { GDP }\end{array}$ & $\begin{array}{l}\text { AVE } \\
\text { GDP }\end{array}$ & $\begin{array}{l}\text { MAX } \\
\text { GDP }\end{array}$ & $\begin{array}{l}\text { SD } \\
\text { GDP }\end{array}$ \\
\hline 1. Hongkong Dollar & 0.86 & 0.0042 & -2.46 & 3.72 & 8.70 & 3.05 \\
\hline 2. US dollar & 0.89 & 0.0042 & -2.78 & 1.79 & 3.79 & 1.60 \\
\hline 3. Saudi Arabia Riyal & 0.94 & 0.0042 & 0.13 & 5.11 & 9.96 & 3.06 \\
\hline 4. Singapore Dollar & 1.24 & 0.0045 & -0.95 & 5.26 & 15.24 & 4.27 \\
\hline 5. $\quad$ Chinese Yuan (Renminbi) & 1.24 & 0.0043 & 6.90 & 9.62 & 14.19 & 2.02 \\
\hline 6. $\quad$ Swiss Franc & 1.35 & 0.0081 & -2.94 & 1.10 & 2.79 & 1.41 \\
\hline 7. Canadian Dollar & 1.60 & 0.0064 & -2.95 & 1.96 & 3.20 & 1.54 \\
\hline $\begin{array}{ll}8 . & \text { Euro }\end{array}$ & 1.69 & 0.0072 & -5.62 & 1.14 & 4.08 & 2.37 \\
\hline 9. $\quad$ British Pound & 1.92 & 0.0068 & -4.19 & 1.78 & 3.34 & 1.89 \\
\hline 10. Australian Dollar & 2.02 & 0.0087 & 1.82 & 2.91 & 4.15 & 0.78 \\
\hline 11. New Zealand Dollar & 2.04 & 0.0088 & -1.31 & 2.60 & 4.87 & 1.71 \\
\hline 12. Japanese Yen & 2.15 & 0.0077 & -5.53 & 0.74 & 4.71 & 2.22 \\
\hline $\begin{array}{l}\text { 13. United Arab Emirates } \\
\text { Dirham }\end{array}$ & 3.03 & 0.0035 & -5.24 & 4.26 & 9.84 & 3.78 \\
\hline
\end{tabular}

Table 2. Time-dependent entropy and standard deviation on logarithmic returns of FX rates on a daily basis, Gross Domestic Product, (2001-2015). 
Previous empirical studies of currency crisis did not try to interpret associations concerning the currency crisis and the extent of its macroeconomic influence. Table 3 shows the calculation of possible correlation existed between the mean economic growth to assess if financial crisis influences the competence of economic growth of a country. Findings, somehow do not support any evidence that logarithmic returns of FX rates have a significant correlation on the potential real economic growth in any term.

\begin{tabular}{|l|c|c|c|c|}
\hline \multirow{2}{*}{} & \multicolumn{2}{|c|}{ Minimum Annual GDP } & \multicolumn{2}{c|}{ Average Annual GDP } \\
\cline { 2 - 5 } & $\begin{array}{c}\text { Entropy } \\
\text { Ordering }\end{array}$ & $\begin{array}{c}\text { Standard Deviation } \\
\text { Ordering }\end{array}$ & $\begin{array}{c}\text { Entropy } \\
\text { Ordering }\end{array}$ & $\begin{array}{c}\text { Standard Deviation } \\
\text { Ordering }\end{array}$ \\
\hline $\begin{array}{l}\text { Spearman's } \\
\text { rho }\end{array}$ & -0.327 & -0.525 & -0.448 & -0.044 \\
\hline Asymp. Sig. & 0.275 & 0.066 & 0.124 & 0.886 \\
\hline
\end{tabular}

Table 3. Measure of correlation between Annual GDP (in terms of minimum and average and Different Ordering Methods (Entropy and standard deviation ordering).

Different entropy movements could be explained as the FX market change from a less or a more chaotic condition. Table 4 presents the changes in entropy values as influenced with the global financial crisis (2007 - 2009), which is considered to be the newest financial crisis that affect all global financial markets. It can be observed that entropy takes high values during period of global financial crisis (2007 to 2009) especially for US dollar and Hongkong dollar currencies. For most (nine or 69.2 percent of 13) of the currencies understudy, FX rate entropy take on high values after a year (for at most three years) period of global currency crisis. This elevated entropy implicates that there is a lack of order or predictability in FX markets produced by chaotic movements in FX rates. The three-year global financial crisis affected most of financial markets and yielded remarkable fluctuations of FX rates. These results confirm previous studies that currency crises are related to remarkable trends in FX rates and hence, decrease stability in FX market forces at work.

\begin{tabular}{|c|c|c|c|c|c|c|}
\hline \multirow{3}{*}{ Currency } & \multicolumn{6}{|c|}{ Entropy Coefficients } \\
\hline & \multirow{2}{*}{ (2001-2015) } & (2001-2003) & $\begin{array}{l}(2004- \\
2006)\end{array}$ & \multirow{2}{*}{$\frac{(2007-2009)}{\begin{array}{c}\text { (financial } \\
\text { crisis })\end{array}}$} & (2010-2012) & $\begin{array}{l}(2013- \\
2015)\end{array}$ \\
\hline & & \multicolumn{2}{|c|}{ (Before financial crisis) } & & \multicolumn{2}{|c|}{ (After financial crisis) } \\
\hline 1. Japanese Yen & 2.15 & 2.07 & 2.85 & 2.69 & 2.72 & 2.75 \\
\hline $\begin{array}{l}\text { 2. Singapore } \\
\text { Dollar }\end{array}$ & 1.24 & 0.88 & 2.82 & 2.81 & 2.71 & 2.83 \\
\hline $\begin{array}{l}\text { 3. } \begin{array}{l}\text { Hongkong } \\
\text { Dollar }\end{array} \\
\text { Dor }\end{array}$ & 0.86 & 0.68 & 2.81 & 2.84 & 2.86 & 2.75 \\
\hline $\begin{array}{ll}\text { 4. } & \text { Chinese } \\
\text { Yuan } \\
\text { (Renminbi) }\end{array}$ & 1.24 & 0.68 & 2.59 & 2.28 & 2.85 & 2.60 \\
\hline $\begin{array}{ll}\text { 5. } & \text { British } \\
\text { Pound }\end{array}$ & 1.92 & 1.55 & 2.87 & 2.78 & 2.84 & 2.34 \\
\hline 6. Euro & 1.69 & 1.92 & 2.87 & 2.78 & 2.86 & 2.79 \\
\hline 7. Swiss Franc & 1.35 & 2.07 & 2.87 & 2.83 & 2.24 & 1.15 \\
\hline 8. US dollar & 0.89 & 0.68 & 2.78 & 2.83 & 2.86 & 2.68 \\
\hline 9. Canadian & 1.60 & 1.57 & 2.87 & 2.84 & 2.84 & 2.83 \\
\hline
\end{tabular}


International Journal on Information Theory (IJIT) Vol.6, No.1/2, April 2017

\begin{tabular}{|c|c|c|c|c|c|c|}
\hline Dollar & & & & & & \\
\hline $\begin{array}{c}\text { 10. Saudi Arabia } \\
\text { Riyal }\end{array}$ & 0.94 & 0.69 & 2.79 & 2.85 & 2.88 & 2.77 \\
\hline $\begin{array}{c}\text { 11. United Arab } \\
\text { Emirates } \\
\text { Dirham }\end{array}$ & $3.03 * *$ & - & - & $*$ & 2.86 & 2.71 \\
\hline $\begin{array}{c}\text { 12. Australian } \\
\text { Dollar }\end{array}$ & 2.02 & 2.24 & 2.86 & 2.32 & 2.81 & 2.84 \\
\hline $\begin{array}{c}\text { 13. New Zealand } \\
\text { Dollar }\end{array}$ & 2.04 & 2.14 & 2.86 & 2.58 & 2.84 & 2.85 \\
\hline
\end{tabular}

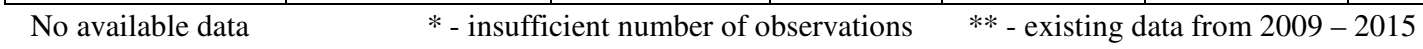

Table 4. Entropy coefficients in every window of three years, before, during, and after global financial crisis of $2007-2009$.

\section{CONCLUSION}

In this paper, the researcher investigates the influence of global currency crises on various FX markets. The use of block entropy method in time series which is the appropriate procedure in catering nonstationary time series was used to logarithmic returns (in a day-to-day basis) of 13 FX rates relative to Philippine Peso. For US dollar and Hongkong dollar currencies, global financial crises are related with elevated values in entropy, which yield from remarkable fluctuations in FX rates and indicates that there is perplexity in FX markets produced by chaotic movements in FX rates.

For most of the currencies understudy, entropy in exchange rate takes on low quantities in time of global financial crisis (2007-2009) but entropy values increase after a year (for at most three years) period of global financial crisis. The entropy approach in time series has presented valuable in describing and computing essential features of FX market movement in time of global financial crises.

\section{REFERENCES}

[1] Baba, N. and F. Packer. 2009. From turmoil to crisis: dislocations in the FX swap market before and after the failure of Lehman Brothers. Journal of International Money Finance, p. 28.

[2] Cajueiro, D.O., and B. M. Tabak. 2004. The Hurst exponent over time: testing the assertion that emerging markets are becoming more efficient. Physica A 336 (3)(2004). pp. 521-537.

[3] Chuluun, T., C.S. Eun, and R. Kiliç. 2011. Investment intensity of currencies and the random walk hypothesis: cross-currency evidence. Journal of Banking Finance 35 (2) 2011). pp. 372-387.

[4] Darko, S., D. Stocik, T. Ludermir, W. de Oliveria and T. Stosic. 2016. Foreign exchange rate entropy evolution during financial crises. www.elsevier.com.http://dx.doi.otg/10.1016/j.physa.2015.12.124.

[5] David, M. and G. Ortega. 2005. Economic growth and currency crisis: A real exchange rate entropic approach. http://mpra.ub.uni-muenchen.de/211/MPRA Paper No. 2111, posted 7. October 2006.

[6] Melvin, M. and M.P. Taylor. 2009. The crisis in the foreign exchange market. Journal of International Money Finance 28 (8) (2009). pp.1317-1330.

[7] Kohler, M. 2010. Exchange rates during financial crises, BIS Quart. Rev. (2010. pp. 39-50.

[8] Shannon, C., 1948. A mathematical theory of communication, Bell Systems Tech. 27, pp. 379-723.

[9] The World Bank. 2017. Retrieved March 1, 2017 from http://www.worldbank.org/.

[10] Zunino, B.M. Tabak, A. Figliola, D.G. Pérez, M. Garavaglia, and O.A. Rosso. 2008. A multifractal approach for stock market inefficiency, Physica A 387 (26) (2008). pp. 6558-6566. 
International Journal on Information Theory (IJIT) Vol.6, No.1/2, April 2017

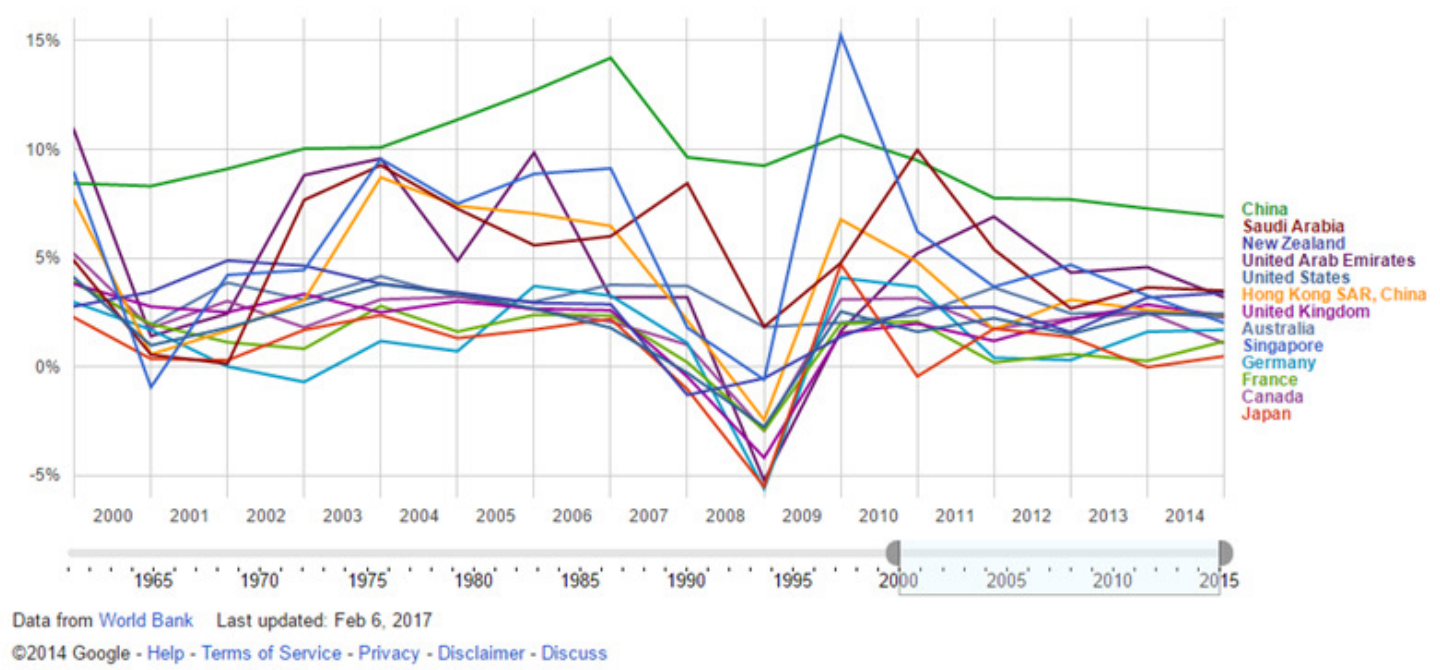

\begin{tabular}{|c|c|c|c|c|c|c|c|c|c|c|c|c|c|c|c|}
\hline \multirow{2}{*}{ Currency } & \multicolumn{15}{|c|}{ GDP } \\
\hline & 2001 & 2002 & 2003 & 2004 & 2005 & 2006 & 2007 & 2008 & 2009 & 2010 & 2011 & 2012 & 2013 & 2014 & 2015 \\
\hline 1. Japanese Yen & 0.36 & 0.29 & 1.69 & 2.36 & 1.30 & 1.69 & 2.19 & -1.04 & .5 .53 & 4.71 & -0.45 & 1.74 & 1.36 & -0.03 & 0.47 \\
\hline 2. Singapore Dollar & .0 .95 & 4.21 & 4.44 & 9.55 & 7.49 & 8.86 & 9.11 & 1.79 & .0 .60 & 15.24 & 6.21 & 3.67 & 4.68 & 3.26 & 2.01 \\
\hline 3. Hongkong Dollar & 0.56 & 1.66 & 3.06 & 8.70 & 7.39 & 7.03 & 6.46 & 2.13 & .2 .46 & 6.77 & 4.81 & 1.70 & 3.07 & 2.61 & 2.36 \\
\hline $\begin{array}{l}\text { 4. Chinese Yuan } \\
\text { (Renminbi) }\end{array}$ & 8.30 & 9.09 & 10.02 & 10.08 & 11.35 & 12.69 & 14.19 & 9.62 & 9.23 & 10.63 & 9.48 & 7.75 & 7.68 & 7.27 & 6.90 \\
\hline 5. British Pound & 2.76 & 2.49 & 3.34 & 2.49 & 3.00 & 2.66 & 2.59 & -0.47 & -4.19 & 1.54 & 1.97 & 1.18 & 2.16 & 2.85 & 2.33 \\
\hline 6. Euro & 1.70 & 0.00 & -0.71 & 1.17 & 0.71 & 3.70 & 3.26 & 1.08 & -5.62 & 4.08 & 3.66 & 0.41 & 0.30 & 1.60 & 1.69 \\
\hline 7. Swiss Franc & 1.95 & 1.12 & 0.82 & 2.79 & 1.61 & 2.37 & 2.36 & 0.20 & .2 .94 & 1.97 & 2.08 & 0.18 & 0.58 & 0.26 & 1.16 \\
\hline 8. US dollar & 0.98 & 1.79 & 2.81 & 3.79 & 3.35 & 2.67 & 1.78 & -0.29 & -2.78 & 2.53 & 1.60 & 2.22 & 1.49 & 2.43 & 2.43 \\
\hline 9. Canadian Dollar & 1.77 & 3.01 & 1.80 & 3.09 & 3.20 & 2.62 & 2.06 & 1.00 & -2.95 & 3.08 & 3.14 & 1.75 & 2.22 & 2.47 & 1.08 \\
\hline 10. Saudi Arabia Riyal & 0.55 & 0.13 & 7.66 & 9.25 & 7.26 & 5.58 & 5.99 & 8.43 & 1.83 & 4.76 & 9.96 & 5.38 & 2.67 & 3.64 & 3.49 \\
\hline $\begin{array}{l}\text { 11. United Arab } \\
\text { Emirates Dirham }\end{array}$ & 1.40 & 2.43 & 8.80 & 9.57 & 4.86 & 9.84 & 3.18 & 3.19 & .5 .24 & 1.64 & 5.21 & 6.89 & 4.32 & 4.57 & 3.18 \\
\hline 12. Australian Dollar & 1.93 & 3.86 & 3.07 & 4.15 & 3.21 & 2.98 & 3.76 & 3.71 & 1.82 & 2.02 & 2.38 & 3.63 & 2.44 & 2.50 & 2.26 \\
\hline 13. New Zealand Dollar & 3.44 & 4.87 & 4.64 & 3.81 & 3.40 & 2.93 & 2.86 & -1.31 & .0 .54 & 1.37 & 2.69 & 2.74 & 1.58 & 3.17 & 3.39 \\
\hline
\end{tabular}

Source: Data from World bank

Appendix 2. Data on GDP of 13 Countries, 2000 - 2015.

Tests of Normality

\begin{tabular}{|l|r|r|r|r|r|r|}
\hline & \multicolumn{3}{|c|}{ Kolmogorov-Smirnov } & \multicolumn{3}{c|}{ Shapiro-Wilk } \\
\cline { 2 - 7 } & \multicolumn{1}{|c|}{ Statistic } & \multicolumn{1}{c|}{ df } & \multicolumn{1}{c|}{ Sig. } & \multicolumn{1}{c|}{ Statistic } & \multicolumn{1}{c|}{ df } & \multicolumn{1}{c|}{ Sig. } \\
\hline Entropy Ordering & .126 & 13 & $.200^{*}$ & .927 & 13 & .316 \\
Variance Ordering & .256 & 13 & .020 & .868 & 13 & .049 \\
AVEGDP & .176 & 13 & $.200^{*}$ & .876 & 13 & .064 \\
MINGDP & .168 & 13 & $.200^{*}$ & .852 & 13 & .030 \\
\hline
\end{tabular}

*. This is a lower bound of the true significance.

a. Lilliefors Significance Correction 
International Journal on Information Theory (IJIT) Vol.6, No.1/2, April 2017

\begin{tabular}{|c|c|c|c|c|}
\hline \multicolumn{5}{|c|}{ Correlations } \\
\hline & & & $\begin{array}{l}\text { Entropy } \\
\text { Ordering } \\
\end{array}$ & MINGDP \\
\hline \multirow[t]{6}{*}{ Spearman's rho } & \multirow[t]{3}{*}{ Entropy Ordering } & Correlation Coefficient & 1.000 & -.327 \\
\hline & & Sig. (2-tailed) & & .275 \\
\hline & & $\mathrm{N}$ & 13 & 13 \\
\hline & \multirow[t]{3}{*}{ MINGDP } & Correlation Coefficient & -.327 & 1.000 \\
\hline & & Sig. (2-tailed) & .275 & \\
\hline & & $\mathrm{N}$ & 13 & 13 \\
\hline
\end{tabular}

\begin{tabular}{|lll|r|r|}
\hline & & \multicolumn{1}{c|}{$\begin{array}{c}\text { Entropy } \\
\text { Ordering }\end{array}$} & AVEGDP \\
\hline Spearman's tho & Entropy Ordering & 1.000 & -.448 \\
& & Correlation Coefficient &. & .124 \\
& Sig. (2-tailed) & 13 & 13 \\
\cline { 2 - 5 } & $\mathrm{N}$ & -.448 & 1.000 \\
& AVEGDP & Correlation Coefficient & .124 &. \\
& Sig. (2-tailed) & 13 & 13 \\
& $\mathrm{~N}$ & & \\
\end{tabular}

\begin{tabular}{|c|c|c|c|c|}
\hline \multicolumn{5}{|c|}{ Correlations } \\
\hline & & & $\begin{array}{l}\text { Variance } \\
\text { Ordering }\end{array}$ & MINGDP \\
\hline \multirow[t]{6}{*}{ Spearman's rho } & \multirow[t]{3}{*}{ Variance Ordering } & Correlation Coefficient & 1.000 & -.525 \\
\hline & & Sig. (2-tailed) & & .066 \\
\hline & & $\mathrm{N}$ & 13 & 13 \\
\hline & \multirow[t]{3}{*}{ MINGDP } & Correlation Coefficient & -.525 & 1.000 \\
\hline & & Sig. (2-tailed) & .066 & \\
\hline & & $\mathrm{N}$ & 13 & 13 \\
\hline
\end{tabular}

Correlations

\begin{tabular}{|rll|r|r|}
\hline & & $\begin{array}{c}\text { Variance } \\
\text { Ordering }\end{array}$ & AVEGDP \\
\hline Spearman's tho & Variance Ordering & Correlation Coefficient & 1.000 & -.044 \\
& & Sig. (2-tailed) &. & .886 \\
& $\mathrm{~N}$ & 13 & 13 \\
\cline { 2 - 5 } & AVEGDP & Correlation Coefficient & -.044 & 1.000 \\
& Sig. (2-tailed) & .886 &. \\
& $\mathrm{~N}$ & 13 & 13 \\
\hline
\end{tabular}

Appendix 3. Statistical results of the study. 


\section{AUTHORS}

Cleo S. Villanueva is an Assistant Professor in Capiz State University, Graduate of Bachelor of Science in Computer Science from System Technology Institute - Roxas and Master in Information Technology from University of the Philippines - Los Banos, currently taking up Doctor of Information Technology in Technology Institute of the Philippines.

Jasmin D. Niguidula is a Professor in TIP Manila. She holds degrees in Bachelor of Science in Computer Science from the Technological Institute of the Philippines and Master of Information Technology from the Technological University of the Philippines. She is also the Chair of Computer Science / Information Systems at Technological Institute of the Philippines

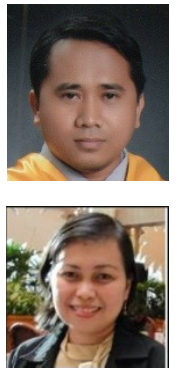

